\title{
Analisis Faktor Faktor yang Mempengaruhi Nilai Tukar Petani Tanaman Pangan di Kabupaten Jombang
}

\section{Analysis of Factors that Affecting Farmers Exchange Rage of Food Crops in Jombang}

\author{
Arlia Renaswari Nirmala ${ }^{1^{*}}$, Nuhfil Hanani ${ }^{2}$, Abdul Wahib Muhaimin ${ }^{2}$ \\ ${ }^{1}$ Pascasarjana Fakultas Pertanian, Universitas Brawijaya \\ ${ }^{2}$ Jurusan Sosial Ekonomi, Fakultas Pertanian, Universitas Brawijaya, Jl. Veteran Malang 65145, Jawa \\ Timur, Indonesia
}

Diterima: 9 Agustus 2016; Direvisi: 3 Oktober 2016; Disetujui: 10 Oktober 2016

\begin{abstract}
ABSTRAK
Nilai Tukar Petani (NTP) merupakan salah satu ukuran dalam penentuan kesejahteraan. Penelitian ini bertujuan untuk mengetahui perkembangan posisi NTP Padi dan Nilai Tukar Petani komoditas pangan lain di Indonesia, mengetahui penghitungan NTP Padi dan menganalisis faktor-faktor yang berpengaruh terhadap NTP Padi. Penelitian dilakukan di Kabupaten Jombang, Jawa Timur. Metode analisis yang digunakan yaitu ratio harga laspeyres antara harga yang diterima terhadap yang dibayar petani. Untuk mengetahui faktor-faktor yang berpengaruh terhadap NTP menggunakan Regresi Linier Berganda. Hasil penelitian menunjukkan bahwa nilai tukar petani dari tahun dasar mengalami kenaikan dan penurunan pada tahun berikutnya. Pada Tahun 2015 nilai tukar petani berada pada kondisi yang cukup sejahtera.
\end{abstract}

Kata kunci: NTP; kesejahteraan; pangan; regresi

\section{ABSTRACT}

Exchange Value of Farmers (EVF) is one measure in determining welfare. This research are intended to identify development of the position of EVF and that of other food commodities in Indonesia in general, identify calculation of EVF paddy and analyze factors that influenced EVF paddy. Research was done in Jombang district, East Java. Analysis method used in this study is Laspeyres price ratio between the price received to that paid by farmers. To know the factors that affect the EVF using Multiple Linear Regression. The research results show that the EVF from the base year has increased and decreased in the following year. In 2015 the exchange rate of the farmers are in a fairly prosperous condition.

Keyword: EVF; welfare; food crops; regression

\section{Pendahuluan}

Hakekat dari pembangunan pertanian yaitu bertujuan untuk meningkatkan kesejahteraan masyarakat sektor pertanian. Mengingat sektor pertanian merupakan sektor yang berhubungan dengan kehidupan masyarakat. Menurut Simaupang (1992) dalam Rachmat (2000) sektor pertanian merupkan sektor perekonomian berbasis sumber daya lokal yang mempunyai peran yang cukup besar terhadap pembangunan suatu negara khususnya negara berkembang seperti Indonesia.

Orientasi pembangunan pertanian kearah perbaikan kesejahteraan petani, akan sangat relevan untuk mengkaji dampak pembangunan

\footnotetext{
${ }^{*}$ Penulis Korespondensi.

E-mail: arlianaswari@yahoo.com
}

yang dilaksanakan terhadap perbaikan kesejahteraan petani, agar dapat menjadi masukan bagi pelaksanaan pembangunan pertanian selanjutnya (Indraningsih dkk., 2003). Salah satu indikator yang bisa dipakai untuk melihat kesejahteraan petani adalah nilai tukar petani (NTP). NTP merupakan hubungan antara hasil yang dijual petani dengan barang dan jasa yang dibeli petani. Dengan kata lain NTP merupakan alat ukur kemampuan tukar barangbarang (produk) pertanian yang dihasilkan petani dengan barang atau jasa yang diperlukan untuk konsumsi rumah tangga petani dan keperluan dalam memproduksi barang-barang pertanian (Hendayana, 2001).

Simatupang dan Maulana (2008) mengemukakan bahwa penanda kesejahteraan yang unik bagi rumahtangga tani praktis tidak ada, sehingga NTP menjadi pilihan satu-satunya 
bagi pengamat pembangunan pertanian dalam menilai tingkat kesejahteraan petani. Dengan demikian, NTP merupakan salah satu indikator relatif tingkat kesejahteraan petani. Semakin tinggi NTP, relatif semakin sejahtera tingkat kehidupan petani (Masyhuri, 2007).

Hal tersebut pula yang terjadi di Kabupaten Jombang. Dimana sektor pertanian masih mempunyai peranan tinggi terhadap pembangunan daerah khususnya Kabupaten Jombang. Pernyataan tersebut diperkuat dengan tingginya lahan yang digunakan untuk pertanian. BPS (2015) mengatakan bahwa lebih dari 50\% lahan di kabupaten Jombang digunakan untuk kegiatan pertanian.

Maka dari itu perlu diketahui besaran kesejahteraan untuk petani khususnya petani tanaman pangan dengan menggunakan NTP sebagai indikator kesejahteraan. Hal inidiperuntukkan supaya mengetahui seberapa sejahtera petani tanaman pangan sehingga pemerintah dapat mengambil langkah untuk meningkatkan kesejahteraan.

\section{Metode Penelitian}

\subsection{Metode Pengumpulan Data}

Penelitian ini akan menggunakan data deret waktu (time series data) dan cross section pada tahun 2015. Data yartg berasai dari Badan Pusat Statistik (BPS)adalah data tentang inflasi berbagai produk pertanian baik saprodi maupun barang modal dan juga inflasi dari produk non usahatani yang dibelanjakan oleh petani tanaman pangan, disamping data penunjang lain yang relevan dari berbagai sumber. Sesuai dengan cakupan data yang ada di BPS, analisa akan dilakukan pada 21 kecamatan di Kabupaten Jombang. Selain data sekunder juga diperlukan data primer yang dilakukan melalui survei lapang dengan menggunakan kuisioner.

\subsection{Metode Analisis Nilai Tukar Petani}

Metode analisis yang digunakan untuk menghitung Nilai tukar petani merupakan hasil formulasi dari Indeks harga Laspeyres seperti yang telah dikembangkan oleh BPS (2995). Nilai Tukar Petani (NTP Padi) didefinisikan sebagai rasio antara harga yang diterima petani (HT) dengan harga yang dibayar petani (HB) atau dapat diformulasikan kedalam rumus:

$\mathrm{NTP}=\frac{\mathrm{IT}}{\mathrm{IB}}$
Dimana:

NTP = Nilai Tukar Petani

IT = Indeks harga yang diterima oleh petani

IB = Indeks harga yang dibayarkan oleh petani

Dimana seperti yang telah disebutkan sebelumnya BPS(1995) mendapatkan NTP dari penurunan indeks Laspeyres sebagai berikut:

$\mathrm{I}=\frac{\sum \mathrm{Q}_{0} * \mathrm{P}_{\mathrm{t}}}{\sum \mathrm{Q}_{0} * \mathrm{P}_{0}}$

Dimana:

I $=$ Indeks Laspeyres

$\mathrm{Q}_{0} \quad=$ Kuantitas pada tahun dasar (2013)

$\mathrm{P}_{0} \quad$ = Harga pada tahun dasar (2013)

$\mathrm{P}_{\mathrm{i}} \quad$ = Harga pada tahun ke $\mathrm{i}$

Sehingga BPS memodifikasi indeks Laspeyres diatas menjadi Indeks harga yang dibayarkan petani dan diterima petani sebagai berikut:

$\mathrm{In}=\frac{\sum_{\mathrm{i}=1}^{\mathrm{m}} \frac{\mathrm{P}_{\mathrm{ni}}}{\mathrm{P}_{(\mathrm{n}-1)^{2}}} \mathrm{P}_{(\mathrm{n}-1) \mathrm{i}} * \mathrm{Q}_{0 \mathrm{i}}}{\sum_{\mathrm{i}=1}^{\mathrm{m}} \mathrm{P}_{0 \mathrm{i}} * \mathrm{Q}_{0 \mathrm{i}}} \times 100$

Dimana:

In $\quad=$ Indeks harga tahunan tahun ke $\mathrm{n}$ (IT dan IB),

$\mathrm{P}_{\mathrm{ni}} \quad=$ Harga tahun ke $\mathrm{n}$ untuk jenis barang ke i,

$\mathrm{P}_{(\mathrm{n}-1) \mathrm{i}}=$ Harga tahunke (n-1) untuk jenis barang ke i,

$\mathrm{P}_{\mathrm{ni}} / \mathrm{P}_{(\mathrm{n}-1) \mathrm{i}}=$ Relatif harga tahun ke $\mathrm{n}$ untuk jenis barang ke i,

$\mathrm{P}_{\mathrm{oi}} \quad=$ Harga dasar tahun dasar untuk jenis barang ke i,

$\mathrm{Q}_{\mathrm{oi}} \quad=$ Kuantitas pada tahun dasar untuk jenis barang ke $\mathrm{i}$,

$\mathrm{m} \quad$ =Banyaknya jenis barang yang tercakup dalam paket komoditas.

Anaslisis Nilai Tukar Petani dihitung dengan mengunakan Microsoft exel sehingga lebih mudah dalam memformulasikan data yang diperoleh.

\subsection{Faktor-Faktor yang Mempengaruhi Nilai Tukar Petani}

Pengukuran pengaruh faktor - faktor yang berpengaruh terhadap NTP menggunakan analisis linier berganda dengan alat bantu SPSS. Data yang dibutuhkan adalah luas lahan petani, Jumlah produksi, harga jual produk tanaman pangan, harga pupuk, pestisida dan nilai tukar 
petani tanaman pangan dengan menggunakan persamaan sebagai berikut:

$\hat{Y}=a+b_{1} X_{1}+b_{2} X_{2}+b_{3} X_{3}+b_{4} X_{4}+b_{5} X_{5}+$ e..(4)

Dimana :

$\hat{\mathrm{Y}} \quad$ : Nilai Tukar Petani

a : Koefisien intercept

b1-b5 : Koefisien regresi

$\mathrm{X} 1$ : Luas Lahan (Ha)

$\mathrm{X} 2$ : Jumlah Produksi (kg)

$\mathrm{X} 3$ : Harga jual $(\mathrm{Rp} / \mathrm{k})$

$\mathrm{X} 4$ : Harga Pupuk (Rp/kg)

X5 : Jumlah Pestisida (Rp/Kg)

e $\quad$ : Koefisien regresi

\section{Hasil dan Pembahasan}

\subsection{Nilai Tukar Petani}

Berdasarkan data yang didapat dari hasil survei yang dilakukan pada tahun 2015, didapatkan Nilai Tukar Petani Tanaman Pangan di Kabupaten Jombang adalah sebesar 100\%.

Tabel 1. Nilai Tukar Petani di Kabupaten Jombang

\begin{tabular}{llccc}
\hline No. & Uraian & $\mathbf{2 0 1 3}$ & $\mathbf{2 0 1 4}$ & $\mathbf{2 0 1 5}$ \\
\hline $\mathbf{1 .}$ & $\begin{array}{l}\text { Indeks yang } \\
\text { Diterima } \\
\text { Petani (It) }\end{array}$ & $\mathbf{6 5 , 3 5 9}$ & $\mathbf{6 0 , 0 4 4}$ & $\mathbf{6 8 , 0 6 8}$ \\
\hline & & & \\
\hline & $\begin{array}{l}\text { 1. Komoditas } \\
\text { Padi }\end{array}$ & 40,479 & 37,310 & 42,297 \\
\hline & $\begin{array}{l}\text { 2. Komoditas } \\
\text { jagung }\end{array}$ & 15,119 & 13,828 & 15,676 \\
\hline & $\begin{array}{l}\text { 3. Komoditas } \\
\text { kedelai }\end{array}$ & 4,300 & 3,943 & 4,470 \\
\hline & $\begin{array}{l}\text { 4. Komoditas } \\
\text { kacang }\end{array}$ & 5,460 & 4,963 & 5,626 \\
\hline 2. & $\begin{array}{l}\text { Indeks yang } \\
\text { Dibayarkan } \\
\text { Petani (Ib) }\end{array}$ & $\mathbf{6 0 , 8 6 3}$ & $\mathbf{6 3 , 6 4 5}$ & $\mathbf{6 8 , 0 5 5}$ \\
\hline & $\begin{array}{l}\text { Makanan dan } \\
\text { Minuman }\end{array}$ & 61,986 & 67,058 & 71,611 \\
\hline & $\begin{array}{l}\text { Non Makanan } \\
\text { dan Minuman }\end{array}$ & 59,341 & 63,588 & 67,921 \\
\hline & BPPBM & 61,261 & 60,291 & 64,634 \\
\hline 3. & $\begin{array}{l}\text { Nilai Tukar } \\
\text { Petani } \\
\text { Pangan }\end{array}$ & $\mathbf{1 , 0 7 4}$ & $\mathbf{0 , 9 4 3}$ & $\mathbf{1 , 0 0 0}$ \\
\hline
\end{tabular}

Nilai Tukar Petani Tanaman Pangan ini didapatkan dari hitungan dengan menggunakan tahun dasar 2012. NTPP tahun 2015 didapatkan dari Indeks diterima petani yaitu 68,068 dibandingkan dengan Indeks harga yang dibayar oleh petni sebesar 68,055. Secara keseluruhan dari perhitungan Nilai Tukar Petani Pangan menunjukkan tinggak kesejahteraan petani tanaman pangan di Kabupaten Jombang.

Tabel 1 menunjukkan bahwa Nilai Tukar Petani Pangan mengalami ke fluktuasi dan berada pada tingkat kesejahteraan yang berbeda. Dimana Nilai Tukar Petani pada tahun 2013 sebesar 107,4 $\%$ yang menunjukkan bahwa pada tahun 2013 petani tanaman pangan berada pada kondisi yang sejahtera. Nilai Tukar Petani Pangan mengalami penurunan kesejahteraan dimana nilai dari NTPP menjadi $94,3 \%$ yang berarti petani mengalami defisit.

Dimana harga barang yang konsumsi petani baik yang digunakan untuk produksi maupun non produksi lebih tinggi dibandingkan dengan harga barang produksi. Berbeda kodisinya pada tahun 2015 dimana NTPP mengalami kenaikan dari tahun 2013 yaitu sebesar $100 \%$. Keadaan seperti ini dimanakan break even dimana tingkat kesejahteraan petani tidak berubah. Indeks harga yang diterima sama dengan indeks harga yang dibayarkan petani. Penyumbang NTP paling besar adalah komoditas jagung dimana pada tahun 2013 dan tahun 2015 NTP komoditas jagung berada pada keadaan surplus yaang menyatakan bahwa pada tahun tesebut petani jagung sejahtera. Meskipun pada tahun 2014 nilai dari NTP petani jagung mengalami defisit namun niali tersebut masih yang paling tinggi dibandingkan dengan petani komoditas lainnya.

Secara keseluruhan nilai NTP tanaman pangan pada tahun 2014 mengalami defisit dimana nilai NTP berada dibawah $100 \%$. Dengan kata lain petani pada tahun 2014 tidak sejahtera. Selain itu keadaan defisit ini disebabkan karena pula karena tingginya inflasi beberapa barang konsumsi pada tahun 2014. Akibat dari inflasi yang semakin melonjak maka menyebabkan harga - harga barang konsumsi semakin mahal. Apabila harga barang konsumsi semakin mahal maka Indeks harga yang dibayarkan semakin besar sedangkan Indeks yang diterima petani lebih kecil sehingga menyebabkan NTP komoditas pertanian menjadi defisit. 
Tabel 2. IB, IT, dan Nilai Tukar Petani Kabupaten Jombang Berdasarkan Komoditas

\begin{tabular}{lccccccccc}
\hline \multirow{2}{*}{ KOMODITAS } & \multicolumn{3}{c}{ IB KABUPATEN } & \multicolumn{1}{c}{ IT PETANI KOMODITAS } & \multicolumn{3}{c}{ NTP } \\
\cline { 2 - 10 } & $\mathbf{2 0 1 3}$ & $\mathbf{2 0 1 4}$ & $\mathbf{2 0 1 5}$ & $\mathbf{2 0 1 3}$ & $\mathbf{2 0 1 4}$ & $\mathbf{2 0 1 5}$ & $\mathbf{2 0 1 3}$ & $\mathbf{2 0 1 4}$ & $\mathbf{2 0 1 5}$ \\
\hline Padi & 38,1802 & 39,925 & 42,733 & 40,479 & 37,310 & 42,297 & 1,060 & 0,935 & 0,990 \\
\hline Jagung & 13,6767 & 14,288 & 15,287 & 15,119 & 13,828 & 15,676 & 1,105 & 0,968 & 1,025 \\
\hline Kedelai & 4,0271 & 4,208 & 4,478 & 4,300 & 3,943 & 4,470 & 1,068 & 0,937 & 0,998 \\
\hline Kacang Tanah & 5,0011 & 5,224 & 5,557 & 5,460 & 4,963 & 5,626 & 1,092 & 0,950 & 1,012 \\
\hline JUMLAH & $\mathbf{6 0 , 8 8 5 1}$ & $\mathbf{6 3 , 6 4 5}$ & $\mathbf{6 8 , 0 5 5}$ & $\mathbf{6 5 , 3 5 9}$ & $\mathbf{6 0 , 0 4 4}$ & $\mathbf{6 8 , 0 6 8}$ & $\mathbf{1 , 0 7 3}$ & $\mathbf{0 , 9 4 3}$ & $\mathbf{1 , 0 0 0}$ \\
\hline
\end{tabular}

Hasil perhitungan It dilihat dari setiap kecamatan mempunyai rataan 3,112 pada tahun 2013, kemudian turun menjadi 2,859 sedangkan pada tahun 2015 kembali meningkat menjadi 3,241. Tabel 3 memperlihatkan nilai It dan $\mathrm{Ib}$ pada masing - masing kecamatan di Kabupaten Jombang. Terdapat 21 Kecamatan yang akan membentuk Nilai Tukar Petani tanaman pangan di Kabupaten Jombang.

Tabel 3. IT, IB, dan Nilai Tukar Petani Berdasarkan Kecamatan di Kabupaten Jombang

\begin{tabular}{|c|c|c|c|c|c|c|c|c|c|c|}
\hline \multirow[t]{2}{*}{ No. } & \multirow[t]{2}{*}{ Kecamatan } & \multicolumn{3}{|c|}{ IT } & \multicolumn{3}{|c|}{ IB } & \multicolumn{3}{|c|}{ NTP } \\
\hline & & 2013 & 2014 & 2015 & 2013 & 2014 & 2015 & 2013 & 2014 & 2015 \\
\hline 1. & $\begin{array}{l}\text { Bandar } \\
\text { Kedungmulyo }\end{array}$ & 4,300 & 3,943 & 4,470 & 4,224 & 4,442 & 4,895 & 101,8 & 88,8 & 91,3 \\
\hline 2. & Bareng & 2,116 & 1,958 & 2,220 & 2,170 & 2,298 & 2,446 & 97,5 & 85,2 & 90,8 \\
\hline 3. & Diwek & 8,635 & 7,900 & 8,955 & 8,232 & 8,616 & 9,200 & 104,9 & 91,7 & 97,3 \\
\hline 4. & Wonosalam & 4,334 & 3,957 & 4,485 & 4,083 & 4,263 & 4,536 & 106,2 & 92,8 & 98,9 \\
\hline 5. & Gudo & 1,092 & 0,993 & 1,125 & 1,057 & 1,097 & 1,164 & 103,3 & 90,5 & 96,7 \\
\hline 6. & Jogoroto & 2,150 & 1,972 & 2,235 & 1,833 & 1,901 & 2,035 & 117,3 & 103,7 & 109,8 \\
\hline 7. & Jombang & 4,266 & 3,930 & 4,455 & 3,645 & 3,790 & 4,061 & 117,0 & 103,7 & 109,7 \\
\hline 8. & Kabuh & 3,208 & 2,951 & 3,345 & 3,126 & 3,255 & 3,477 & 102,6 & 90,6 & 96,2 \\
\hline 9. & Sumobito & 3,208 & 2,951 & 3,345 & 2,957 & 3,082 & 3,281 & 108,5 & 95,7 & 101,9 \\
\hline 10. & Kesamben & 5,392 & 4,936 & 5,595 & 4,912 & 5,117 & 5,447 & 109,8 & 96,4 & 102,7 \\
\hline 11. & Kudu & 3,174 & 2,937 & 3,330 & 2,942 & 3,069 & 3,266 & 107,9 & 95,7 & 101,9 \\
\hline 12. & Plandaan & 4,232 & 3,916 & 4,439 & 3,850 & 4,048 & 4,308 & 109,9 & 96,7 & 103,1 \\
\hline 13. & Megaluh & 3,174 & 2,937 & 3,330 & 3,017 & 3,174 & 3,379 & 105,2 & 92,5 & 98,5 \\
\hline 14. & Mojoagung & 2,116 & 1,958 & 2,220 & 2,038 & 2,127 & 2,263 & 103,8 & 92,1 & 98,1 \\
\hline 15. & Mojowarno & 2,150 & 1,972 & 2,235 & 2,164 & 2,279 & 2,426 & 99,3 & 86,5 & 92,1 \\
\hline 16. & Perak & 3,242 & 2,964 & 3,360 & 2,919 & 3,032 & 3,226 & 111,1 & 97,8 & 104,1 \\
\hline 17 & Peterongan & 2,150 & 1,972 & 2,235 & 2,100 & 2,194 & 2,334 & 102,4 & 89,9 & 95,7 \\
\hline 18. & Ngusikan & 2,150 & 1,972 & 2,235 & 2,005 & 2,095 & 2,226 & 107,2 & 94,1 & 100,4 \\
\hline 19. & Ngoro & 2,116 & 1,958 & 2,220 & 1,792 & 1,867 & 1,987 & 118,1 & 104,9 & 111,7 \\
\hline 20. & Ploso & 1,092 & 0,993 & 1,125 & 0,866 & 0,901 & 1,038 & 126,2 & 110,1 & 108,4 \\
\hline 21. & Tembelang & 1,058 & 0,979 & 1,110 & 0,955 & 0,997 & 1,062 & 110,8 & 98,2 & 104,5 \\
\hline & Rataan & 3,112 & 2,859 & 3,241 & 2,899 & 3,031 & 3,241 & 107,3 & 94,3 & 100,0 \\
\hline
\end{tabular}

Perkembangan nilai $\mathrm{Ib}$ di Kabupaten Jombang dari tahun 2013-2015 mengalami kenaikan dari tahun ke tahun. Dimana pada tahun 2013 besaran Ib yaitu 2,899, yang kemudian meningkat pada tahun selanjutnya sebesar 3,031. Sama halnya yang terjadi pada tahun 2015 dimana nilai dari rataan $\mathrm{Ib}$ di Kabupaten Jombang juga mengalami kenaikan yaitu sebesar 3,241. Tabel 3 telah menunjukkan bahwa nilai It mengalami tidak konstan, yaitu mengalami naik turun besaran nilainya. Berbeda halnya dengan $\mathrm{Ib}$ yang mengalami peningkatan pada setiap tahunnya yang nantinya juga akan mempengaruhi besaran NTPP menjadi surplus atau defisit. Berbeda dengan Indek harga yang diterima oleh petani, Indeks harga yang dibayarkan dari tahun ketahun di setiap kecamatan mengalami kenaikan secara terus menerus. Hal ini disebabkan karena harga kebutuhan bahan pokok yang semakin naik, meskipun harga tersebut mengalmi penurunan namun tidak terlihat secara sigifikan. Setelah adanya krisis moneter di Indonesia, 
hampir semua kebutuhan pokok mengalami kenaikan harga. Hal tersebut dapat meningkatkan nilai indeks harga yang dibayarkan oleh petani sehingga akan mempengaruhi tingkat kesejahteraan petai.

Kecamatan Diwek mempunyai It tertinggi dibandingkan dengan kecamatan lainnya dimana perbedaan iru sangat terlihat pada diagram perkembangan Indeks Harga yang Diterima oleh petani tanaman pangan. Kecamatan Diwek mempunyai It sebesar 8,232 yang cukup tinggi di Kabupaten Jombang. Setelah Kecamatan Diwek yang junga menyumbang It cukup besar adalah Kecamatan Kesamben yaitu sebesar 5,595. Sedangkan Kecamatan Gudo merupakan penyumbang It paling kecil diantara Kecamatan yang lainnya. Indeks harga yang diterima oleh petani dipengaruhi oleh jumlah hasil produksi dan harga jual dari pruoduk pertanian tersebut.

\subsection{Faktor-faktor yang mempengaruhi Nilai Tukar Petani Tanaman Pangan Kabupten Jombang}

Table 4. Hasil Pengujian Parameter Duga Regresi Secara Parsial

\begin{tabular}{lccc}
\hline \multicolumn{1}{c}{ Variabel X } & $\mathbf{B}$ & $\mathbf{t}_{\text {hitung }}$ & Signifikan \\
\hline Konstanta & 0,982 & & \\
\hline Luas Lahan & $-0,992$ & $-1,670$ & $0,101^{* *}$ \\
\hline $\begin{array}{l}\text { Hasil } \\
\text { Produksi } \\
\text { yang Dijual }\end{array}$ & 0,838 & 1,871 & $0,067^{* *}$ \\
$\begin{array}{l}\text { Harga Jual } \\
\text { Produk }\end{array}$ & 2,085 & 2,210 & $0,031^{*}$ \\
\hline Pupuk & $-1,711$ & $-2,002$ & $0,050^{*}$ \\
\hline Pestisida & $-0,035$ & -0.040 & $0,968^{* *}$ \\
\hline
\end{tabular}

Keterangan : *Signifikan ; **Tidak Signifikan

Tabel 4. di atas merupakan tabel hasil pengujian signifikansi parameter duga secara simultan, di mana dapat diketahui bahwa nilai signifikansi yang diperoleh sebesar 0,076. Koefisien determinasi $\left(R^{2}\right)$ merupakan besaran yang memberikan informasi goodnes of fit dari persamaan regresi, yaitu memberikan proporsi atau presentase kekuatan pengaruh variabel variabel bebas terhadap nilai tukar petani.

Berdasarkan hasil analisis regresi diperoleh nilai $R^{2}$ sebesar 0,159 . Hasil tersebut menjelaskan sumbangan atau kontribusi dari variabel-variabel bebas dalam mempengaruhi variabel $\mathrm{Y}$ adalah sebesar $15,9 \%$, sedangkan $84,1 \%$ lainnya disumbangkan oleh variabel lainnya yang tidak dimasukkan ke dalam persamaan ini.
Jika dibandingkan dengan $\alpha=10 \%$ maka nilai signifikansi uji $\mathrm{F}$ tersebut lebih kecil daripada $\alpha$. Hal ini menunjukkan bahwa keputusan yang diambil adalah Tolak $\mathrm{H}_{0}$ atau dengan kata lain terdapat pengaruh Luas Lahan,Hasil Produksi yang Dijual, Harga Jual Produk, Pupuk dan Pestisida terhadap Nilai Tukar Petani secara bersama-sama pada tingkat kepercayaan $90 \%$.

Berdasarkan Tabel 4 di atas diperoleh signifikansi sebesar 0,101 yang lebih besar dari 0,05 dan nilai $\left|t_{\text {hitung }}\right|=1,670<t_{\text {tabel }}=2,00$. Pengujian ini menunjukkan bahwa $\mathrm{H}_{0}$ diterima sehingga disimpulkan bahwa Luas Lahan tidak berpengaruh signifikan terhadap Nilai Tukar Petani.

Variabel Hasil Produksi yang Dijual memiliki signifikansi sebesar 0,067 yang bernilai lebih besar daripada 0,05 dan juga nilai $\mathrm{t}_{\text {hitung }}=1,871<\mathrm{t}_{\text {tabel }}=2,00$. Pengujian ini menunjukkan bahwa $\mathrm{H}_{0}$ diterima sehingga disimpulkan bahwa Hasil Produksi yang Dijual tidak berpengaruh signifikan terhadap nilai tukar petani.

Variabel Harga Jual Produk memiliki signifikansi sebesar 0,031 yang bernilai lebih kecil daripada 0,05 dan juga nilai $t_{\text {hitung }}=2,210>$ $\mathrm{t}_{\text {tabel }}=2,00$. Pengujian ini menunjukkan bahwa $\mathrm{H}_{0}$ ditolak sehingga disimpulkan bahwa Harga Jual Produk berpengaruh signifikan terhadap nilai tukar petani. Besarnya nilai $b_{3}$ adalah 2,085 dan bertanda negatif memiliki arti bahwa ketika harga jual produk meningkat $1 \%$ maka nilai tukar petani akan meningkat sebesar 2,085\%.

Variabel pupuk memiliki signifikansi sebesar 0,050 yang bernilai sama besar dengan 0,05 dan juga nilai $\left|t_{\text {hitung }}\right|=2,00$ sama dengan $\mathrm{t}_{\text {tabel }}=2,00$. Pengujian ini menunjukkan bahwa $\mathrm{H}_{0}$ ditolak sehingga disimpulkan bahwa Harga pupuk berpengaruh signifikan terhadap nilai tukar petani. Besarnya nilai $b_{4}$ adalah $-1,711$ dan bertanda negatif memiliki arti bahwa ketika harga pupuk meningkat $1 \%$ maka nilai tukar petani akan menurun sebesar $1,711 \%$.

Variabel pestisida memiliki signifikansi sebesar 0,968 yang bernilai lebih besar dari 0,05 dan juga nilai $\left|t_{\text {hitung }}\right|=0,040<t_{\text {tabel }}=2,00$. Pengujian ini menunjukkan bahwa $\mathrm{H}_{0}$ diterima sehingga disimpulkan bahwa Harga pestisida tidak berpengaruh signifikan terhadap nilai tukar petani. 


\section{Kesimpulan}

Nilai tukar petani dari tahun 2013-2015 beragam tingkatannya pada tahun 2013 nulai tukar prtani diatas 100 persen sehingga petani tanaman pangan pada tahun tersebut berada dalam kondisi sejahtera. Sebaliknya pada tahun 2014 nilai tukar petani berada dalam keadaan defisit sehingga pada tahun tersebut terlihat kesejahteraan petani tanaman pangan mengalami penurunan atau kurang sejahtera. Tahun 2015 nilai tukar petani naik dari kondisi sebelumnya yaitu menyamai batas kesejahteraan yaitu $100 \%$ sehingga berada dalam kondisi cukup sejahtera. Hasil dari analisis menyatakan bahwa indikator pengeluaran petani memberikan nilai yang lebih tinggi daripada harga produk pertanian sehingga menyebabkan penurunan Nilai Tukar Petani.

Harga jual produk dan harga pupuk berpengaruh nyata terhadap nilai tukar petani pangan. Sedangkan produksi, luas lahan, dan pestisida tidak berpengaruh nyata terhadap nilai tukar petani. Hal ini disebabkan karena semakin tinggi luas lahan usahatani yang dimiliki maka pengeluaran untuk faktor produksi juga akan semakin tinggi.demikian pula produksi dan pestisida menambah pengeluaran usahatani sehingga indeks harga yang dibayarkan melebihi indeks harga yang diterima.

\section{Daftar Pustaka}

Badan Pusat Statistik. 2006. Kabupaten Jombang Dalam Angka. Jombang.

2011. Statistik Nilai Tukar Petani Kabupaten Jombang. BPS. Jombang.

\section{Pertumbuhan Ekonomi} Indonesia. Jakarta.

\section{Kabupaten Jombang} Dalam Angka. Jombang.

BPPD. 2012. Penyusunan Nilai Tukar Petani Kabupaten Jombang. Bappeda Jombang. Jombang.

Burhansyah. 2011. Nilai Tukar Petani dan Faktor-faktor Yang Mempengaruhi Disentra Produksi Jagung Kalimantan Barat. Jurnal Pembangunan Manusia Vol. 5 No.1 Tahun 2011.

Hendayana, R. 2001. Analisis Faktor-Faktor Yang Mempengaruhi Nilai Tukar Petani. Pusat Penelitian dan Pengembangan Sosial Ekonomi Pertanian, Badan Penelitian dan Pengembangan Pertanian. Bogor.
Parabawati. Posisi Nilai Tukar Petani Padi dengan nilai Tukar Petani Komoditas Pangan. JPAL, Vol.1, No.2, Feb 2011.

Rachmat, Muchjidin. 2000. Analisa Nilai Tukar Petani Indonesia. Disertasi. Institut Pertanian Bogor.

Rachmat, et. al. 2000 .Perumusan Kebijaksanaan Nilai Tukar Petani dan Komoditas Pertanian. Laporan Hasil Penelitian. Pusat Penelitian Sosial Ekonomi Pertanian. Depertemen Pertanian. Bogor.

Ruauw. 2010. Nilai Tukar Petani Sebagai Indikator Kesejateraan Petani. Universitas Samratulangi, Manado. ASE - Volume 6 Nomor 2, Mei 2010:1-8.

Simatupang dan Maulana. 2008. Kaji Ulang Konsep dan Pengembangan Nilai Tukar Petani 2003-2006. Jurnal Ekonomi dan Pembangunan. LIPI.

Simatupang, P. dan B. Isdijoso. 1992. Pengaruh Pertumbuhan Ekonomi Terhadap Nilai Tukar Sektor Pertanian. Landasan Teoritis dan Biukti Empiris. Ekonomi dan Keuangan Indonesi 40 (1).

Simatupang, P. 1992. Pertumbuhan Ekonomi dan Nilai Tukar Barter Sektor Pertanian. Jurnal Agroekonomi. 11(1):37-50.

Sumodiningrat. 2001. Kepemimpinan dan Pemberdayaan Ekonomi Rakyat. Pidato Pengukuhan Guru Besar pada Fakuts Ekonomi Universitas Gadjah Mada.

Tambuan. 2003. Perkembangan Sektor Pertanian di Indonesia (bebrapa isu penting). Ghalla. Jakarta. 